\title{
Self-efficacy and academic listening
}

\author{
Article
}

Accepted Version

Graham, S. (2011) Self-efficacy and academic listening. Journal of English for Academic Purposes, 10 (2). pp. 113117. ISSN 1475-1585 doi: https://doi.org/10.1016/j.jeap.2011.04.001 Available at https://centaur.reading.ac.uk/20903/

It is advisable to refer to the publisher's version if you intend to cite from the work. See Guidance on citing.

To link to this article DOI: http://dx.doi.org/10.1016/j.jeap.2011.04.001

Publisher: Elsevier

All outputs in CentAUR are protected by Intellectual Property Rights law, including copyright law. Copyright and IPR is retained by the creators or other copyright holders. Terms and conditions for use of this material are defined in the End User Agreement.

\section{www.reading.ac.uk/centaur}

\section{CentAUR}

Central Archive at the University of Reading

Reading's research outputs online 


\title{
Self-efficacy and academic listening
}

\author{
Suzanne Graham
}

Institute of Education, University of Reading, Bulmershe Court, Earley, Reading, RG6

$$
1 H Y, U K
$$

Email: s.j.graham@ reading.ac.uk

Tel: +44 (0) 1183788838

\begin{abstract}
This paper takes as its starting point the difficulties inherent in listening in a second language. It argues that self-efficacy, broadly defined as the belief in one's ability to carry out specific tasks successfully, is crucial to the development of effective listening skills, and that listening strategy instruction has the potential to boost self-efficacy. The degree of control over the process of listening that learners can gain through listening strategy instruction is an important factor in this process. Reviewing studies that have integrated strategy instruction with measures to address learners' sense of control and self-efficacy for listening, it concludes by arguing that in an EAP context, such a heightened sense of confidence can help learners cope more effectively with authentic oral input.
\end{abstract}

Key words: Academic listening; self-efficacy; learner strategy instruction.

\section{Introduction}


The argument that effective listening does not develop on its own but needs to be fostered explicitly is not a new one (see, for example, Mendelsohn 1994), with recent contributions to the debate emphasising in particular the importance of listening strategy instruction in this process (Vandergrift \& Tafaghodtari, 2010). An argument less frequently made, however, is that effective listening also depends on learners' self-efficacy for listening, on their confidence in their ability to make sense of the input to which they are exposed. This paper considers the role of self-efficacy in listening in a variety of learning contexts and argues that its development is both central to effective listening and an integral part of listening strategy instruction. It then applies the concept to the particular case of the EAP learner.

\section{Listening difficulty}

While a high level of listening skills is widely acknowledged to be vital for success in a number of language learning contexts, including in EAP settings (Ferris \& Tagg, 1996), such effective listening skills do not develop easily. Vandergrift (n.d.) comments that listening is a 'complex, active process of interpretation', far more than just 'extracting meaning from incoming speech'. Furthermore, a range of studies (e.g. Arnold (2000), Goh (2000), Hasan (2000) indicate that across instructional settings, listening is a source of frustration to learners and an area in which it seems difficult to make progress.

In a study of my own (Graham 2006), I asked intermediate school-age learners of French in England to indicate in a questionnaire the language skill area in which they felt they had experienced the least success. Very few students saw listening as a strength, with many more commenting in follow-up interviews on the difficulties that they experienced. These included:

- problems of perception, particularly regarding the speed of delivery of texts;

- difficulties caused by missing or mis-hearing supposedly vital words; 
- problems in identifying words because of the speakers' accent, perhaps indicating a lack of exposure to authentic listening texts.

Perhaps more importantly, students showed signs of demotivation in relation to listening, with one typical participant commenting that she only sometimes made an effort in listening but '...then I just give up because I can't, usually they play it twice, that isn't enough for me' (p. 177). These difficulties will be familiar to those working in EAP programmes, with important implications for how learners operate both in instructional and real-life academic settings.

\section{Self-efficacy}

The student quotation just given reflects a low sense of self-efficacy for listening, a lack of belief in the ability to succeed or improve. Self-efficacy (Bandura, 1993) is an important 'subtheory’ (Dörnyei and Ottó,1998, p.44) within an expectancy-value framework of motivation (as outlined in the work of Eccles and co-authors, e.g. Wigfield and Eccles, 2000). The concept relates to individuals' belief in their capacity to achieve specific tasks, which is held to have a strong influence on levels of persistence and the choices individuals make regarding which activities to pursue. Research has consistently shown that it has a considerable impact on learning outcomes, with a stronger sense of self-efficacy found to lead to higher levels of achievement, a greater willingness to face challenges and to exert effort (Mills, Pajares \& Herron, 2006).

Self-efficacy beliefs are in turn believed to be related to learners' attributions - the explanations that individuals give, consciously or sub-consciously, for how well they have performed on certain tasks (Hsieh \& Shallert, 2008). The level of 'control' inherent in different types of attribution is important in determining whether their influence is positive or negative with regard to motivation and persistence. Controllable and internal attributions, 
such as those relating to the degree of effort exerted or the strategies employed on a task, are likely to be associated with positive self-efficacy beliefs (Graham \& Macaro, 2008; Hsieh \& Shallert, 2008), as the individual can influence the task outcome by altering the amount of effort or the strategies applied. Likewise, if learners can see that there is a connection between what they do and what outcomes result, then their sense of 'instrumentality' (Paris \& Winograd, 1990) is likely to be stronger, with positive influences on their motivation. Elsewhere (e.g. Graham, 2006) I have argued that low self-efficacy may be particularly acute in second language listening because it is a less physically 'observable' skill than, say, writing, and thus seems less controllable. Admittedly, in a classroom or a study centre setting, learners have the opportunity of rewinding recordings for multiple listening - but this is not at all what occurs when they enter the real-world of the academic lecture. There, the listener has no control over the input and cannot 'rewind' to sections that were not understood, or pause if the speech is too fast. The transitory nature of such oral input is thus a potential cause of listening anxiety. Bandura (1997, as cited in Mills et al, 2006: 279) argues that anxiety is linked to low self-efficacy, in that 'it is one's sense of efficacy to control or dismiss apprehensive emotions that accounts for anxiety'. The relationship between self-efficacy, anxiety and listening performance has been explored in a small number of empirical studies. Chen (2007), working with 277 Taiwanese college-level learners of English, found that L2 listening self-efficacy predicted listening scores more strongly than did L2 listening anxiety and the perceived value of English, while Mills et al (2006) found that self-efficacy in listening was positively correlated with listening proficiency (albeit only for female students) and negatively correlated with listening anxiety.

\section{The role of classroom methodology}


It is possible that low levels of self-efficacy for listening are exacerbated by the way in which listening is taught. Indeed, it has been noted by a number of commentators (Chambers, 2007; Field, 2008; Graham, 2006; Graham, Santos \& Vanderplank, forthcoming) that in many language classrooms, listening takes the form of an activity to be 'delivered' rather than a skill to develop in its own right. Teachers interviewed in two studies conducted in UK secondary school contexts (reported in Graham, Santos \& Vanderplank, 2008 and in Graham, 1997) expressed uncertainty as to how listening should be taught, and tended to emphasise quantity of practice rather than quality in terms of actually developing listening as a skill. They reported on the textbook exercises they carried out with learners but were unable to talk about how they taught listening. This research thus seemed to an indicate an approach to listening shaped by convention and textbooks rather than by pedagogic principles, with teachers appearing to believe that listening is a skill mastered simply through repetition and practice.

Likewise, Chambers (1996) outlines what he sees as the typical approach to listening in foreign language classrooms in England: Learners listen to a text and complete an accompanying exercise, the correction of which is the final stage of the listening process. Listening is thus principally a test of comprehension, typically based on an exercise from a textbook, focusing on the understanding of specific details rather than on the global sense of the text. This constitutes what Field (2008) calls the 'Comprehension Approach' and which, he argues, does little to develop effective listening skills. It is also unlikely to develop selfefficacy for listening, through its over-emphasis on 'testing' and lack of insight fostered among learners into how to bring about improvement. Interestingly, a study by Bekleyen (2009) reports high levels of listening anxiety among students aspiring to be language teachers, anxiety which these students attributed to a lack of attention to the skill from their own teachers. The study indicates that these would-be teachers dealt with their own listening 
anxiety as students by simply practising more. This suggests that teachers themselves may have negative experiences in second language listening from their time as students, experiences which may then influence their own teaching as they resort to more practice rather than to a focused programme of development with their own learners.

\section{Boosting self-efficacy}

We thus have a rather negative picture of listening comprehension and self-efficacy. It is important to note, however, that several studies have indicated that self-efficacy for listening, as well as listening performance, is amenable to development, through the explicit teaching of listening strategies, within a model of strategy instruction which has a strong emphasis on scaffolding of learning and learner reflection. Such strategy instruction aims at increasing learners' sense of control and expectations of success, by, in addition to teaching strategies, also offering scaffolding in the form of feedback on strategy use and drawing learners' attention to the link between the strategies used and the outcome achieved. Instruction within this model is also based on learners' needs in terms of where their difficulties lie, so that they can select strategies that are appropriate for certain types of tasks and certain situations, again enhancing their sense of personal control. In a study of intermediate learners of French in England, Graham and Macaro (2008) showed that learners who received listening strategy instruction not only performed significantly better on a listening post-test than those not receiving instruction, their self-efficacy for listening also improved more. Developing learners' metacognitive awareness of how to use strategies effectively was an important part of the project, as was increasing their sense of control over their learning. 
A project outlined in Graham (2007) began with an activity to draw learners' attention to the notion of 'control' in learning, and how it might be achieved. Learners were asked to sort various statements from another group of learners which epitomised either 'control' or 'lack of control' over learning. The contribution of learner strategies to 'control' was then discussed with learners. In addition, students kept diaries on their strategy use, outlining strategies used and what problems they had had with tasks. Importantly, researchers gave feedback on the strategy use recorded in these diaries, encouraging students to try different strategies and to see the relationship between those strategies and how well they completed listening tasks. The greater sense of control that such strategy instruction may develop is indicated by a quotation from one of the study's participants ( p. 90): 'I think my methods have changed really, the way I approach it. I sort of get in the right frame of mind to do it. . . . If something's difficult, I don't sort of like panic about it'.

This echoes very closely a statement from a student in a different context, reported by Yeldham (2009). The study, a qualitative exploration of EFL learners in Taiwan, suggests that a sense of control develops in learners who respond positively to strategy instruction, as one learner explains: 'If I don't understand, don’t panic, keep listening' (Yeldham, 2009, p. 179; see also Graham et al, forthcoming). In a different setting, with young school learners of English in Singapore, Goh and Taib (2006) report that strategy instruction that involved learners in reflecting on and discussing strategy use led not just to improved listening and strategic knowledge, but also to greater reported confidence in listening. This was particularly the case for less proficient learners.

In addition to reflecting on the link between strategy use and how well one listens, verbalisation may be an important element in developing self-efficacy, as the above studies indicate. In a study of 'language deficient' L1 learners at primary school level, Schunk and Rice $(1983,1984)$ found that verbalisation of listening strategies after modelling by a teacher 
helped strengthen learners' self-efficacy and performance. Thus, the teacher modelled the strategies, voiced them out loud and children repeated them verbally before applying them to a task, e.g. 'I'll look at each picture carefully to see if it matches the story I heard' (Schunk \& Rice, 1883: 8). The authors claim that verbalisation helps learners to attend more fully to strategies and aids their 'encoding' (1983, p.4); if verbalisation matches what the teacher has modelled, they continue, then self-efficacy is likely to be further increased as it strengthens the learners' sense of control and 'implies they can succeed if they want to ' (p.5). Furthermore, in their view, the 'pairing' of strategy verbalisation with increased success in particular will also strengthen self-efficacy. Coming from a different perspective but also emphasising the importance of verbalisation, studies conducted within a sociocultural framework suggest that the act of talking about one's strategies to another person, for example in paired listening tasks, can increase listeners' metacognitive awareness (Cross, forthcoming; Vandergrift \& Tafaghodtari, 2010), and hence by implication, increase their sense of control over their listening.

\section{Discussion and implications for EAP pedagogy}

Research into the role of self-efficacy in listening thus seems to underline its importance in terms of listening performance. Within an EAP context, it would seem to be particularly relevant. Nothing can fully prepare a second-language student for the experience of listening to a full-length lecture or participating in a rapid exchange of views in seminar. However, it is important to ensure that these experiences do not give rise to the kind of listening anxiety that forces the student to rely almost exclusively upon visual input (PowerPoint slides and handout) in the first case and remain totally silent in the second. The knowledge that he or she is capable of making sense of what is said to the extent of picking out critical words and phrases and main ideas will give much-needed confidence in the early days of an academic 
course. It will also mark the first step in the gradual and usually imperceptible process that occurs as a listener becomes attuned to a language by dint of extended exposure to it. Some of the contexts in which self-efficacy has been studied relate to younger learners; but the notion would seem particularly apposite when the learners in question are young adults. Negatively, they are more susceptible to a sense of failure and disempowerment if they do not succeed in following a lecture; but positively they are more able to discuss and rationalise their listening problems and to actively apply the types of strategy that might form part of their instruction.

It is possible that EAP practitioners may feel that strategy instruction is heavily classroomoriented, without direct applications to real life performance. Nevertheless, I would argue that it offers important benefits by giving learners the experience of successfully applying tools to crack the code of speech and thus boosting their self-efficacy, with implications for their subsequent participation in real-life listening events.

On a practical level, instructors can help to strengthen learners' self-efficacy for listening by activities that develop their sense of instrumentality, i.e. the awareness that there is a relationship between what one does (for example strategies used) and learning outcomes (e.g. how successfully a listening passage is understood). Simply teaching listening strategies is not sufficient to cultivate instrumentality. Any strategy instruction needs to incorporate stages which help learners see strategy application as a way of gaining control over what the process of comprehension.

Within the widely accepted model of strategy instruction (for an overview, see Rubin, Chamot, Harris, and Anderson, 2007), including consciousness-raising, modelling, practice, evaluation and action-planning, the first step and the last two are especially important. Consciousness-raising, where learners reflect on what strategies are and which ones they use already, also needs to include some exploration of learners' beliefs about listening and the 
extent to which they can exercise control over it. The method outlined in Graham (2007), in which learners were given statements from learners that reflected either control or absence of control and were asked to sort them into control/no control groups, is a useful starting point. After listening strategies have been modelled and practised, learners then need to evaluate their effectiveness in terms of what sort of learning outcome their application led to - did one strategy help more than another for different kinds of academically-related tasks, were different combinations of strategies more effective than others? This and subsequent actionplanning, i.e. planning which strategies to reapply for future listening activities, can encourage strategy-based, controllable and internal attributions, which, as stated earlier, seem to co-exist with a strong sense of self-efficacy.

In addition, levels of self-efficacy seem to be increased by activities that allow adult learners to verbalise and discuss their strategy use. On a practical level this can be achieved by allowing learners to talk in class about the strategies they used on a task and which were helpful, either in groups or in pairs (see, for example, Cross, forthcoming). Or learners can keep logs for out-of class listening work in which they record which strategies they applied, what outcomes they led to and plans for future strategy use. Instructor feedback on such logs, focusing on strategy use, is an important factor in strengthening learners' understanding of how listening outcomes can be controlled.

Such an approach, does, of necessity, move listening classes away from a model whereby the instructor plays a recording, asks learners some comprehension questions about it, assesses how well they have responded, and then moves on to the next task. Some may feel that the more reflective and dialogic approach suggested in this article is too time-consuming. Given the centrality of self-efficacy, however, for listening in general, and for academic listening in particular, it is likely to be time well-spent. 
Self-efficacy for listening in EAP settings is little researched and is an area ripe for further investigation, in terms of learners' levels of self-efficacy and of the extent to which interventions in the classroom can improve it.

\section{References}

Arnold, J. (2000). Seeing through listening comprehension exam anxiety. TESOL Quarterly, 34, 777-786.

Bandura, A. (1993). Perceived self-efficacy in cognitive development and functioning. Educational Psychologist, 28, 117-148.

Bekleyen, N. (2009). Helping teachers become better English students: causes, effects, and coping strategies for foreign language listening anxiety. System, 37, 664-675.

Chambers, G. (1996). Listening, Why? How? Language Learning Journal, 14, 23-27.

Chambers, G. (2007). Developing listening skills in the modern foreign language.

In N. Pachler and A. Redondo (Eds.), A practical guide to teaching modern foreign languages in the secondary school (pp. 50-57). Abingdon: Routledge.

Chen, H-Y. (2007). The relationship between EFL learners' self-efficacy beliefs and English performance. Unpublished $\mathrm{PhD}$ thesis, The Florida State University.

Cross, J. (forthcoming). Raising L2 listeners' metacognitive awareness: a sociocultural theory perspective. Language Awareness.

Dörnyei, Z.\& Ottó, I. (1998). Motivation in action: a process model of L2 motivation Working Papers in Applied Linguistics, Thames Valley University, London, 4, 43-69. Ferris, D., \& Tagg, T. (1996). Academic listening/speaking tasks for ESL students: Problems, suggestions, and implication. TESOL Quarterly, 30, 297-317.

Field, J. (2008). Listening in the language classroom. Cambridge: Cambridge University Press. 
Goh, C.C.M. (2000). A cognitive perspective on language learners' listening comprehension problems. System, 28, 55-75.

Goh, C.C.M. \& Taib, Y. (2006). Metacognitive instruction in listening for young learners. ELT Journal, 60, 222-232.

Graham, S. (1997). Effective language learning. Positive strategies for Advanced Level language learning. Clevedon: Multilingual Matters Ltd.

Graham, S. (2006). Listening comprehension: The learners' perspective System, 34, 165182.

Graham, S. (2007). Learner strategies and self-efficacy: making the connection Language Learning Journal, 35, 81-93.

Graham, S. \& Macaro, E. (2008). Strategy instruction in listening for lower-intermediate learners of French. Language Learning, 58, 747-783.

Graham, S., Santos, D. \& Vanderplank, R. (2008). Selective listening. Paper presented at the $15^{\text {th }}$ Annual Conference of the International Association of Applied Linguistics, Essen, August 2008.

Graham, S., Santos, D. \& Vanderplank, R. (2010). Strategy clusters and sources of knowledge in French L2 listening comprehension International Journal of Innovation in Language Learning and Teaching, 4, 1-20.

Graham, S., Santos, D. \& Vanderplank, R. (forthcoming) Exploring the relationship between listening development and strategy use. Language Teaching Research.

Hasan, A.S. (2000). Learners' perceptions of listening comprehension problems. Language, Culture and Curriculum, 13, 137-153.

Hsieh, P-S. P. \& Schallert, D.L. (2008). Implications from self-efficacy and attribution theories for an understanding of undergraduates' motivation in a foreign language course. Contemporary Educational Psychology, 33, 513-532. 
Mendelsohn, D.J. (1994). Learning to listen. San Diego: Dominie Press.

Mills, N., Pajares, F. \& Herron, C. (2006). A reevaluation of the role of anxiety: self-efficacy, anxiety, and their relation to reading and listening proficiency. Foreign Language Annals, 39, 276-295.

Paris, S. G., \& Winograd, P. (1990). How metacognition can promote academic learning and instruction. In: B.F Jones \& L. Idol (Eds.), Dimensions of thinking and cognitive instruction (pp. 15-51). Hillsdale, NJ: Erlbaum.

Rubin, J., Chamot, A. U., Harris, V., \& Anderson, N. J. (2007). Intervening in the use of strategies. In A. D. Cohen \& E. Macaro (Eds.), Language learner strategies: Thirty years of research and practice (pp. 141-160). Oxford: Oxford University Press.

Schunk, D.H. \& Rice, J.M. (1983). Strategy verbalization effects on self-efficacy and listening comprehension. Paper presented at the Annual Meeting of the American Psychological Association, Annaheim, CA, August 26-30.

Schunk, D.H. \& Rice, J.M. (1984). Strategy self-verbalization during remedial listening comprehension instruction. The Journal of Experimental Education, 53, 49-54.

Vandergrift, L. (n.d.). Listening: theory and practice in modern foreign language competence. Available at: http://www.llas.ac.uk/resources/gpg/67 (Accessed 10 December 2010). Vandergrift, L. \& Tafaghodtari, M.H. (2010). Teaching L2 learners how to listen does make a difference: an empirical study. Language Learning, 60, 470-497.

Wigfield, A. \& Eccles, J. (2000). Expectancy-value theory of achievement motivation. Contemporary Educational Psychology, 25, 68-81.

Yeldham, M.A. (2009). Approaches to second language listening instruction: investigating the top-down/bottom-up debate. Unpublished doctoral dissertation, University of Melbourne, Australia. 
Suzanne Graham is Professor of Language and Education at the University of Reading, Institute of Education. Her research interests include language learner strategies, second language listening comprehension and motivation for language learning. 
There are increasing indications that measures to improve self-efficacy can also help learners to listen more effectively. Within an EAP context, this seems to be especially important, since effective listening makes a key contribution to learners' overall language performance and hence to their ability to participate fully in academic settings. 